\title{
ANALISIS KOMPETENSI GURU DALAM PENERAPAN KURIKULUM 2013
}

\author{
${ }^{1)}$ Yasinta Yenita Dhiki ${ }^{2)}$ Maria Waldetrudis Lidi ${ }^{3)}$ Ningsih
}

Dosen Program Studi Pendidikan Matematika, Fakultas Keguruan dan Ilmu Pendidikan, Universitas Flores, Ende. Email: dhikiyasinta@gmail.com

\begin{abstract}
Abstrak
Kompetensi penting dimiliki oleh guru sebagai fasilitator dalam proses pembelajaran guna menunjang profesionalisme kinerjanya. Oleh karena itu guru perlu memiliki keempat kompetensi, yakni kompetensi pedagogik, kompetensi profesional, kompetensi kepribadian dan kompetensi sosial. Dalam hal ini, peneliti merasa perlu menganalisis keempat kompetensi guru pada 12 Sekolah Dasar se-kabupaten Ende dengan menggunakan pendekatan kuatitatif. Penelitian dilaksanakan pada bulan Juni sampai Oktober Tahun 2017.Teknik pengumpulan data yang digunakan adalah penyebaran kuesioner kepada informan yaitu pada guru dan siswa untuk mengetahui keempat kompetensi guru. Berdasarkan hasil analisis jawaban responden terhadap keempat kompetensi Guru disimpulkan bahwa guru dan siswa sama-sama memberikan penilaian cukup baik pada tiga kompetensi guru, yaitu kompetensi pedagogik, kompetensi kepribadian dan kompetensi sosial. Sedangkan pada kompetensi profesional penilaian siswa dikategorikan baik dan penilaian guru dikategorikan cukup baik.
\end{abstract}

Kata Kunci: Kompetensi Pedagogik, Kompetensi Profesional, Kompetensi Kepribadian Dan Kompetensi Sosial

\section{PENDAHULUAN}

Kurikulum memiliki peranan yang penting dalam menciptakan pendidikan yang berkualitas bagi masyarakat. Sebagaimana tertuang dalam UU Republik Indonesia No 20 tahun 2003, kurikulum berisikan tujuan, isi, dan segala perencanaan yang menentukan arah dan proses pendidikan. Sebagai suatu rencana pembelajaran, kurikulum perlu diaplikasikan dalam proses pembelajaran di kelas. Oleh karena itu, kurikulum dan pembelajaran tidak dapat dipisahkan karena merupakan suatu kesatuan yang saling berkaitan.

Kurikulum 2013 adalah kurikulum berbasis kompetensi dan karakter secara terpadu yang merupakan penyempurnaan dari KTSP. Kurikulum ini dipandang sesuai dengan program pendidikan yang berbeda dengan kurikulum sebelumnya. Dalam penerapannya, kurikulum membutuhkan praktisioner yang akan menjalankan rencana - rencana yang tertulis dalam dokumen kurikulum tersebut. Untuk itu, guru adalah faktor penting dalam pengimplikasian kurikulum karena guru yang berinteraksi langsung dengan siswa. Guru berperan dalam pengembangan kurikulum itu sendiri yakni dalam proses pembelajaran di kelas. Oleh karena itu, guru diharapkan mampu memfasilitasi siswa secara efektif agar siswa berperan aktif dalam mengembangkan dirinya untuk mencapai berbagai kecakapan. Namun, sering kali seorang guru, khususnya yang belum memiliki banyak pengalaman mengajar, memilih metode pengajaran

Makalah dipresentasikan dalam Seminar Nasional Pendidikan Dasar dengan tema " Inovasi Pembelajaran menyenangkan di Tingkat Pendidikan Dasar " pada tanggal 2 Desember 2017 di Program Studi PGSD Universitas Flores Ende. 
secara acak tanpa mengetahui teori yang mendasarinya dan tanpa mempertimbangkan karakteristik siswa.

Hal ini tentunya berdampak pada kualitas pembelajaran dan mutu guru itu sendiri dan juga mutu siswa. Oleh karena itu guru dituntut untuk memiliki kompetensi. Dalam Peraturan Menteri Nasional RI Nomor 16 Tahun 2007 tentang Standar Kompetensi Akademik dan Kompetensi Guru menyebutkan bahwa guru harus menguasai empat kompetensi utama, yakni kompetensi pedagogik, kompetensi profesional, kompetensi kepribadian, dan kompetensi sosial. Dari hasil penelitian yang dilakukan oleh Sahat Renol HS (2015) menyimpulkan bahwa kompetensi guru memiliki pengaruh yang signifikan terhadap prestasi belajar siswa.

Berdasarkan data tersebut diatas, maka perlu adanya analisis terhadap kompetensi guru SD di kabupaten Ende dalam penerapan kurikulum 2013. Ada pun tujuan penelitian ini yakni untuk mengidentifikasi kompetensi guru SD di Kabupaten Ende dalam penerapan kurikulum 2013. Penelitian ini diharapkan bermanfaat untuk 1) Dinas Pendidikan: dengan adanya informasi tentang kompetensi guru, Pemerintah Kabupaten Ende dapat menentukan kebijakan dalam pelaksanaan kurikulum; 2) Bagi Guru, hasil penelitian dijadikan informasi untuk guru-guru untuk meningkatkan kompetensi profesionalitasnya bagi peningkatan kualitas sumber daya manusia sesuai tujuan pendidikan; 3) Bagi Peneliti, memberikan informasi tentang kesiapan guru dalam kompetensi pedagogik, sehingga informasi tersebut menjadi dasar bagi penelitian lanjutan atau pelatihan profesi bagi guru-guru di Kabupaten Ende.

\section{METODE PENELITIAN}

Jenis penelitian yang digunakan dalam penelitian ini adalah penelitian kuantitatif.. Data-data yang dikumpulkan berupa kata-kata yang kemudian diubah dalam bentuk data kuantitatif dengan penskoran. Data yang terkumpul dianalisis menggunakan statistik deskriptif. Penelitian ini dilaksanakan di 12 SD se-Kabupaten Ende, Propinsi Nusa Tenggara Timur pada bulan Juni sampai Oktober Tahun 2017. Teknik pengumpulan data yang digunakan dalam penelitian ini adalah penyebaran kuesioner kepada informan yaitu pada guru dan siswa untuk mengetahui kompetensi pedagogik guru. Kuesioner yang diberikan adalah kuesioner tertutup, di mana pada kuesioner ini peneliti telah menyediakan alternatif jawaban dan responden memberikan tanda check list pada jawab yang sesuai dengan responden.

Teknik analisis data menggunakan teknik analisis statistik deskriptif yaitu dengan menggunakan skala likert. Untuk keperluan analisis secara kuantitatif maka jawaban-jawaban diberi skor sebagai berikut.

1. Selalu dengan skor 4.

2. Sering dengan skor 3. 
3. Jarang dengan skor 2 .

4. Tidak pernah dengan skor 1 .

Angka-angka kemudian dianalisis dengan perhitungan presentase sebagai berikut.

$$
P=\frac{f}{N} \times 100 \%
$$

Keterangan:

$\mathrm{P}=$ Presentase

$\mathrm{f}=$ Frekuensi

$\mathrm{N}=\mathrm{Jumlah}$ populasi

Nilai persentase yang diperoleh selanjutnya dikategorikan dengan kriteria sebagai berikut.

Tabel. 1. Kriteria Persentase Respon Siswa

\begin{tabular}{cc}
\hline Persentase (\%) & Kategori \\
\hline 80- 100 & Sangat baik \\
$60-79$ & Baik \\
$30-59$ & Cukup baik \\
$0-29$ & Kurang baik \\
\hline & Diadopsi dari Riduwan $(2010)$
\end{tabular}

\section{HASIL DAN PEMBAHASAN}

Berdasarkan hasil sebaran kuesioner tentang keempat kompetensi pada responden yaitu pada guru dan peserta didik maka diperoleh hasil yang dapat dilihat pada tabel di bawah ini. Tabel 2 adalah rangkuman persepsional siswa tentang kompetensi pedagogik guru, sedangkan penilaian diri oleh guru dapat dilihat pada Tabel 3.

Tabel 2 Persepsional Peserta didik

\begin{tabular}{llcccc}
\hline \multirow{2}{*}{ No } & \multirow{2}{*}{ Kompetensi } & Selalu & Sering & Jarang & Tidak pernah \\
\hline \multirow{2}{*}{1} & Pedagogik & 51.82 & 28.43 & 10.70 & 7.47 \\
2 & Kepribadian & 55.43 & 26.88 & 10.17 & 6.02 \\
3 & Profesional & 66.72 & 21.45 & 6.95 & 3.24 \\
4 & Sosial & 58.68 & 25.74 & 10.66 & 3.21 \\
\hline
\end{tabular}




\begin{tabular}{cccccc}
\hline \multicolumn{6}{c}{ Tabel 3 Penilaian diri Guru } \\
\cline { 2 - 5 } No & Kompetensi & Selalu & Sering & Jarang & Tidak Pernah \\
\hline 1 & Pedagogik & 51.6 & 30.8 & 8.98 & 1.58 \\
2 & Kepribadian & 70.8 & 18.3 & 3.58 & 0.25 \\
3 & Profesional & 49.9 & 25.3 & 12.1 & 5.67 \\
4 & Sosial & 20.6 & 30.7 & 22 & 19.35 \\
\hline
\end{tabular}

Dari tabel di atas dapat dideskripsikan rata-rata hasil penskoran keempat kompetensi guru, sebagai berikut:

Hasil pernilaian siswa menunjukkan bahwa kompetensi pedagogik guru yang menyatakan selalu berjumlah 51.82, yang menyatakan sering 28.43, dan yang menyatakan jarang berjumlah 10.70, sedangkan siswa yang menyatakan tidak pernah 7.47. Dalam kompetensi kepribadian,yang menyatakan selalu 55.43, siswa yang menyatakan sering 26.88, yang menyatakan jarang 10.17 , dan tidak pernah berjumlah 6.02. Hasil rerata penilaian siswa pada kompetensi profesional yang menyatakan selalu berjumlah 66.72 , penilaian siswa yang menyatakan sering 21.45 , dan yang menyatakan jarang berjumlah 6.95 , sedangkan penilaian siswa yang menyatakan tidak pernah berjumlah 3.24. Selanjutnya, pada kompetensi sosial, diperoleh penilaian selalu 58.68, yang menyatakan sering 25.74 , siswa yang menilai jarang berjumlah 10.66 dan siswa yang menyatakan tidak pernah berjumlah 3.21 .

Penilaian diri oleh guru pada kompetensi pedagogik yang menyatakan selalu berjumlah 51.6, guru yang menyatakan sering berjumlah 30.8, yang menyatakan jarang berjumlah 8.98, sedangkan 1.58 menyatakan tidak pernah. Pada kompetensi kepribadian sebanyak 70.8 menyatakan selalu, yang menyatakan sering 18.3, sebanyak 3.58 menyatakan jarang dan 0.25 menyatakan tidak pernah. Dalam penilaian diri guru pada kompetensi profesional yang menyatakan selalu sebanyak 49.9, 25.3 menyatakan sering, yang menyatakan jarang berjumlah 12.1, dan guru yang menyatakan tidak pernah sebanyak 5.67. Demikian juga pada kompetensi sosial, guru yang menyatakan selalu sebanyak 20.6, yang menyatakan sering 30.7, sebanyak 22 menyatakan jarang dan 19.35 menyatakan tidak pernah.

Penilaian keempat kompetensi tersebut dianalisis berdasarkan rentangan penilaian yang dimodifikasi dari Ridwan (2010) dimana diperoleh hasil penilaian siswa pada kompetensi pedagogik dinilai cukup baik, kompetensi kepribadian dinilai cukup baik, kompetensi profesional dinilai baik, dan kompetensi sosial dinilai cukup baik. Kemudian, untuk penilaian diri oleh guru 
pada kompetensi kompetensi pedagogik dinilai cukup baik, kompetensi kepribadian dinilai baik, kompetensi profesional dinilai cukup baik, dan kompetensi sosial dinilai cukup baik.

Berdasarkan hasil penelitian diatas, diketahui bahwa tidak ada perbedaan penilaian terhadap kompetensi guru baik yang diberikan oleh siswa maupun guru itu sendiri. Sedikit perbedaan hanya terlihat pada penilaian kompetensi profesional dimana penilaian siswa dikategorikan baik, sedangkan penilaian diri oleh guru dikategorikan cukup baik.

\section{PENUTUP}

\section{Kesimpulan}

Berdasarkan hasil pembahasan bab empat (4) dapat disimpulkan bahwa guru dan siswa sama-sama memberikan penilaian cukup baik pada tiga kompetensi guru, yaitu kompetensi pedagogik, kompetensi kepribadian dan kompetensi sosial. Sedangkan pada kompetensi profesional penilaian siswa dikategorikan baik dan penilaian guru dikategorikan cukup baik. Oleh karena itu, guru SD perlu meningkatkan kompetensinya.

\section{Saran}

1) Guru perlu meningkatkan profesionalismenya khususnya pada kompetensi pedagogik.

2) Pemerintah perlu memberikan pelatihan kepada guru-guru yang berkaitan dengan kompetensi guru.

\section{DAFTAR PUSTAKA}

Peraturan Menteri Pendidikan Nasional Republik Indonesia Nomor 16 Tahun 2007 tentang Standar Kualifikasi Akademik dan Kompetensi Guru. 2007. Jakarta.

Riduwan. 2010. Skala Pengukuran Variabel-Variabel Penelitian. Alfabeta.Bandung

Sahat, R. H.S. 2015. "Pengaruh Kompetensi Guru dan Motivasi Belajar Siswa Terhadap Prestasi Belajar Siswa Kelas Xi Ips Sma Negeri 17 Medan”. Prosiding Semiar Nasional Pendidikan Ekonomi \& Bisnis, Fakultas Keguruan dan Ilmu Pendidikan, Universitas Sebelas Maret Surakarta. Sabtu, 07 November 2015.

Sanjaya, W. 2011. Kurikulum dan Pembelajaran. Kencana Prenada Media Group. Jakarta. Suhandani dan Julia. 2014. "Identifikasi Kompetensi Guru Sebagai Cerminan Profesionalisme Tenaga Pendidik Di Kabupaten Sumedang (Kajian Pada Kompetensi Pedagogik)". Jurnal Mimbar Sekolah Dasar Volume 1 No. 2, 2014m Hal 128-141.

Umami dan Roesminingsih. 2014. "Pengaruh Kompetensi Pedagogik dan Motivasi Kerja Guru Terhadap Prestasi Belajar Siswa Dalam Ujian Nasional Di SMA Negeri Se Kota Mojokerto". Jurnal Inspirasi Manajemen Pendidikan, Vol. 3, No 3, 2014, Hal 81-88.

Ummah, K. 2013. "Analisis Kompetensi Guru Matematika Berdasarkan Persepsi Siswa". Jurnal Pendidikan Matematika STKIP PGRI Sidoarjo, Vol 1, No.1, 2013, hal 51-60.

Undang-Undang No 20 Tahun 2003 Tentang Sistem Pendidikan Nasional.Jakarta: Fokus Media Pengembangan Kurikulum 2013.Diakses di www.slidehared.net tanggal 20 Juni 2017. 